\title{
Performance of Litchi (Litchi Chinensis Sonn.) Air Layers during Different Season: A Need for Optimization of Layering Period
}

\author{
Ezekiel Reang ${ }^{1}$, Julius Uchoi ${ }^{2}$ and Hidangmayum Lembisana Devi ${ }^{3}$ \\ ${ }^{1}$ College of Agriculture Tripura, Lembucherra, West Tripura-799210, India \\ ${ }^{2}$ ICAR-Central Arid Zone Research Institute (CAZRI), RRS, Jaisalmer-345001, India \\ ${ }^{3}$ ICAR Research Complex for NEH Region, Tripura Centre, Lembucherra-799210, India \\ *Corresponding author
}

\begin{abstract}
A B S T R A C T
Litchi (Litchi chinensis Sonn.) is one of the major crops of India having high demand both in domestic and international market. Availability of genuine planting material at low cost

Keywords

Litchi, Propagation,

Air layering,

Season, Planting

material, Success

percent

\section{Article Info}

Accepted:

15 July 2018

Available Online:

10 August 2018

is one of the major issues for area expansion under this crop. Currently the widely adopted method of propagation is air layering, which is practiced mostly during the monsoon season, as a result only limited numbers of planting materials are generated. The success rate of air layering is dependent upon various factors like season, hormones, physiology and environmental condition. The objective of our study was to test the feasibility of extending the time of operation of air layering based on success percentage and other growth parameters. The result of the investigation revealed a reasonable performance of all the parameters throughout the seasons, although significant higher values were noticed during monsoon season in most of the parameters. A significant $(\mathrm{p}<0.05)$ highest values in terms of number of secondary root (19.50), fresh weight $(1.85 \mathrm{~g})$, dry weight $(1.05 \mathrm{~g})$ and earliest root initiation (36.00 days) were observed during the month of July. Maximum success percent $(85 \%)$ and number of primary root $(10.20)$ were recorded during the month of August. While the maximum values for shoot length $(50.30 \mathrm{~cm})$, number of leaves $(56.25)$ and root length $(8.57 \mathrm{~cm})$ were noticed during the month of September, March and June respectively.
\end{abstract}

\section{Introduction}

Litchi (Litchi chinensis Sonn.) a subtropical fruit crop belonging to the family Sapindaceae is one of the major fruit crop of India having export potential. Large scale cultivation of suitable cultivars are constrained by the absence of easy and reliable clonal propagation methods and the use of modern techniques like micro propagation is not very successful in litchi (Amin, 1996). Indiscriminate use of planting material from unreliable source and its substitution for good quality planting material has resulted in low production and productivity (Wahab et al., 2001). There is very low success rate with grafting and cuttings (Abutiate and Nakasone, 1972) and incompatibility between stock and scion is pronounced (Mergen, 1954) in litchi. Seedling trees are not true-to-type and results 
in fruits of various size and quality (Crane and Balerdi, 2008).

Low rooting potential, high transplanting shock and poor field establishments are other factors that contribute to low rate of production of quality planting materials (Kumar, 2012). Air layering is the commercially adopted method of propagation in litchi; however operational period is restricted to few months (monsoon season) at present, which is inadequate to generate sufficient quantity of planting material to meet the growing demands of genuine planting material. The rate of success of air layering also varies with location. The success in air layering is a function of several factors like season, physiological maturity of shoot, hormones, environmental factors (temperature, humidity and rainfall), orientation of branch, skill and their interaction (Kumar, 2012). Hence we hypothesized that season could hold a vital clue in extending the time of operation of air layering.

The previous research in the related area includes; effects of dates on layering performance in particular agro ecological zone (Dhillon and Mahajan, 2000), Combined effect of time and plant growth regulator to enhance rooting and survival (Rahman et al., 2002), selection of best season and rooting medium (de Linss et al., 2015) effects of rooting media in relation to air layering success (Ali et al., 2016), optimum dose of growth regulator (NAA) to enhance success percentage (Abbas et al., 2016) etc.

However the problem of low production of quality planting material is yet to be fully addressed. Therefore, the objective of our study was to test the feasibility of extending the time of operation of air layering based on success percentage and other growth parameters.

\section{Materials and Methods}

The study was conducted at Horticultural Research Station (HRS), Mondouri under Faculty of Horticulture. Bidhan Chandra Krishi Viswavidyalaya, West Bengal during the year 2013 and 2014. The experimental site experiences a sub tropical humid climate in general, with distinct winter (November to February) and summer (June to October). The mean minimum and maximum temperatures are in the range of 10 to $40^{\circ} \mathrm{C}$ and the average annual rainfall varies from 1200 to $1500 \mathrm{~mm}$.

The technical procedure for selection of shoots and mother plants were done as per the method described by Patel et al., 2012. For the purpose of study, ten mother plants (cv. Bombai) of uniform age and vigour, free from disease and pest were selected. Each of the mother plants were considered as individual blocks and all the blocks were given uniform cultural practice during the experimental period. Ten uniform twigs from all the directions were selected from each of the mother plant.

The method of Kumar (2012) was followed for air layering. A bark along with cambium and phloem was removed just below the node, leaving the xylem intact. This was achieved by making two parallel cuts $1 \frac{1}{2}$ inch apart using sharp knife around the stem, through the bark and cambium layer. The parallel cuts were connected by an incision and the ring of bark was removed, exposing the inner woody tissue. The cambial tissue present over the xylem was scrapped to prevent the formation of callus bridge. The wound portion of the stem was sealed by surrounding it with a handful of moist soil ball to act as rooting media. The moist soil ball was wrapped with a transparent plastic and fastened with jute thread at the top and bottom, so as to retain the moisture. 
The layers were severed from the mother plant after 90 days of operation and five layers were randomly selected from each replication (Kumar, 2000) and subsequently the data for all the parameters were recorded. Root length (longest root) was assessed as per the method described by Bouma et al., (2000) using image analysis software. Dry weights of the roots were recorded after drying in an oven for 72 hours at $70^{\circ} \mathrm{C}$ (Abbas et al., 2016).

The experiment was conducted following complete randomised design, consisting of three replications. The mean data of two years was subjected to analysis of variance (ANOVA) and the significance of treatment was detected by least significant difference (LSD) at 5\% probability level, which was computed using SAS V.9.1 (SAS Institute Inc., NC, USA) software.

\section{Results and Discussion}

The overall performance of air layering across different months revealed encouraging trends, although better performance in most of the parameters were observed in the monsoon months the other seasons also presented a satisfactory performance.

The air layering operation conducted across various seasons showed a significant $(\mathrm{p}<$ 0.05 ) influence over the number of days required to initiate rooting (Fig. 1). Layers took lesser time to initiate rooting when conducted during monsoon months (July, August and September), whereas layer took relatively longer time to initiate rooting in the month of February and March. A significant $(p<0.05)$ superior result was recorded in the month of July; in contrast the month of March took longest time to initiate rooting. This may be attributed to high metabolic activity leading to greater synthesis and storage of carbohydrate during monsoon as opined by de Lins (2015). Kumar (2012) also reported that season has pronounced effect in regeneration of roots in air layering. The results corroborates the findings of Nautiyal (2002) where he reported that root initiation was more in July, compared to other months due to higher temperature.

The effect of season showed a significant $(\mathrm{p}<$ 0.05 ) influence on success percentage of layers which revealed a unique pattern, where a peak was observed in the month of August and a gradual decline thereafter to the lowest value in the month of February (Fig. 2). The availability of requisite moisture could be the reason for higher success during monsoon season as reported by Kadami and Debral (1954) and Nautiyal (2002), in addition health and vigor of the trees that were used could have also played a significant role (Hartmann et al., 2002). Our results support the earlier findings of Dhillon and Mahajan, 2000 on the same crop where they recorded the success percent in the range of $80-85 \%$ during the monsoon season. A similar result (85\%) was also reported by Souza et al., (2016) in litchi through the use of bio-stimulants. However the report of Rajendra et al., (2013) contradicts our result where they obtained higher values up to $95 \%$ in Jamaican ackee.

The values recorded for number of leaves revealed an unusual trend where spring and summer months recorded better results contrary to the notion that better results are obtained only in the monsoon season (Table 1). A significant $(\mathrm{p}<0.05)$ superior value (56.25) was recorded in the month of March which is statistically similar to the values recorded in the month of February. The better results during summer months in terms of number of leaves can be explained by the fact that vegetative growth is favoured in the temperature range of 20 and $35^{\circ} \mathrm{C}$ with optimum around $30^{\circ} \mathrm{C}$, furthermore the rising temperature also favours cell division resulting in more sprout production (de Lins, 
2015). Our results are in line with that of Ali et al., 2013 on the same crop, whereas the report of Dhillon and Mahajan, 2000 contradicts our results owing to much inferior results (24.5).

A similar pattern was also observed in length of shoot $(\mathrm{cm})$, where better performance can be observed across all the seasons and not confined to a particular season (Table 1). The maximum value was recorded in the months of September (50.30) and lowest during June (31.60). The optimum environmental condition prevailing during the experimental period may have favoured greater cell division leading to more production of vegetative growth (L.C.R. de Lins, 2015). These results support the earlier findings of Sud (2005) on the same crop. However it is in contradictory with the finding of Patil et al., (2004) in pomegranate.

The values for number of primary root obtained for layering under different season showed a pattern corresponding with that of success percentage, where higher values were observed during the rainy season and lower values during the other season (Table 1). A significant $(\mathrm{p}<0.05)$ maximum value was noticed in the month of August (10.20) while the month of March recorded the minimum value (4.50). The greater values during the rainy season may be attributed to several factors like physiological conditions, age of the mother plant, hormonal balance, temperature, light, humidity and substrate (Hartman, 2011 and Rios et al., 2012). In addition the favourable water balance during monsoon due to high rainfall and humidity may be the other factor for the better result. Rajendra et al., (2013) working with different dose of IBA obtained a higher result (40.0) in Jamaican ackee. Our result contradicts the report of Souza et al., (2016) where they reported a much lower value (0.71). However, our results are in line with that of Rahman et al., (2002).
The data on secondary root (Table 1) revealed a pattern where a good performance was observed across all seasons although maximum (14.20) and minimum (8.30) were observed during the month of July and September. The better results in secondary root formation can be ascribed to factors like mineral nutrition, hormonal balance and water availability (Almeida et al., 2004). The results of our study are in conformity with the result (18.0) of Kumar (2000) when air layering was done in the month of July in litchi cv. Shahi. Lavania et al., (1995) in jackfruit and Singh (2002) in guava also observed similar results with regard to secondary roots.

Root length determines the ability to adapt to stress conditions, as layer roots have been associated with high efficiency to assimilate water and nutrient from the soil (RuizSanchez et al., 2005). Air layering in different months exhibited a significant $(\mathrm{p}<0.05)$ influence on root length. The trends in data recorded across different seasons were at par, except for the month of June where the maximum value (8.57) was recorded. The availability of carbohydrates which acts as a source of carbon and energy for the biosynthesis of nucleic acids and proteins, and other substances essential to the formation of roots could be the probable reason for better performance (Lima et al., 2011). Rajendra et al., 2013 reported a higher result (13.4), while similar results were reported by Souza et al., 2016 and Rahman et al., (2002).

A significant $(\mathrm{p}<0.05)$ influence of season on fresh weight $(\mathrm{gm})$ of roots were observed (Table 1). The higher values were detected when the operations were performed during the rainy season, while relatively lower values were observed in the other months. The peak performance was observed in the month of July $(1.85 \mathrm{gm})$. The better result with fresh weight (gm) can be due to enhanced rooting as a result of higher photosynthetic products like 
carbohydrates coupled with favourable by treatment with $10000 \mathrm{ppm}$ IBA in the environmental condition (Rajendra et al., month of July. These results also corroborate 2013). These results are in comparison to the the earlier findings of Kumar et al., (2000). findings of Singh (2002). A similar finding However our results contradicts the findings was also reported by Lavania et al., (1995) of Rajendra et al., (2013) as they have where they obtained maximum value of $4.0 \mathrm{~g}$ reported a lower value $(0.7)$

Table.1 Effect of seasons of operation of air layers on growth parameters of litchi

\begin{tabular}{|l|c|c|c|c|c|c|c|}
\hline & $\begin{array}{c}\text { Length of } \\
\text { shoot }(\mathrm{cm})\end{array}$ & $\begin{array}{c}\text { No. of } \\
\text { leaves } \\
\text { per layer } \\
(90 \mathrm{DAO})\end{array}$ & $\begin{array}{c}\text { No. of } \\
\text { primary } \\
\text { roots } \\
(90 \mathrm{DAO})\end{array}$ & $\begin{array}{c}\text { No. of } \\
\text { secondary } \\
\text { roots } \\
(90 \mathrm{DAO})\end{array}$ & $\begin{array}{c}\text { Root } \\
\text { Length } \\
(\mathrm{cm})\end{array}$ & $\begin{array}{c}\text { Fresh weight } \\
\text { of roots }(\mathrm{g})\end{array}$ & $\begin{array}{c}\text { Dry } \\
\text { weight of } \\
(90 \mathrm{DAO})\end{array}$ \\
\begin{tabular}{|l} 
roots $(\mathrm{g})$ \\
$(90 \mathrm{DAO})$
\end{tabular}
\end{tabular}

DAO - Days after operation

Fig.1 Effect of seasons of operation on days required to initiate rooting. The data points represent LSD at $5 \%$ probability level

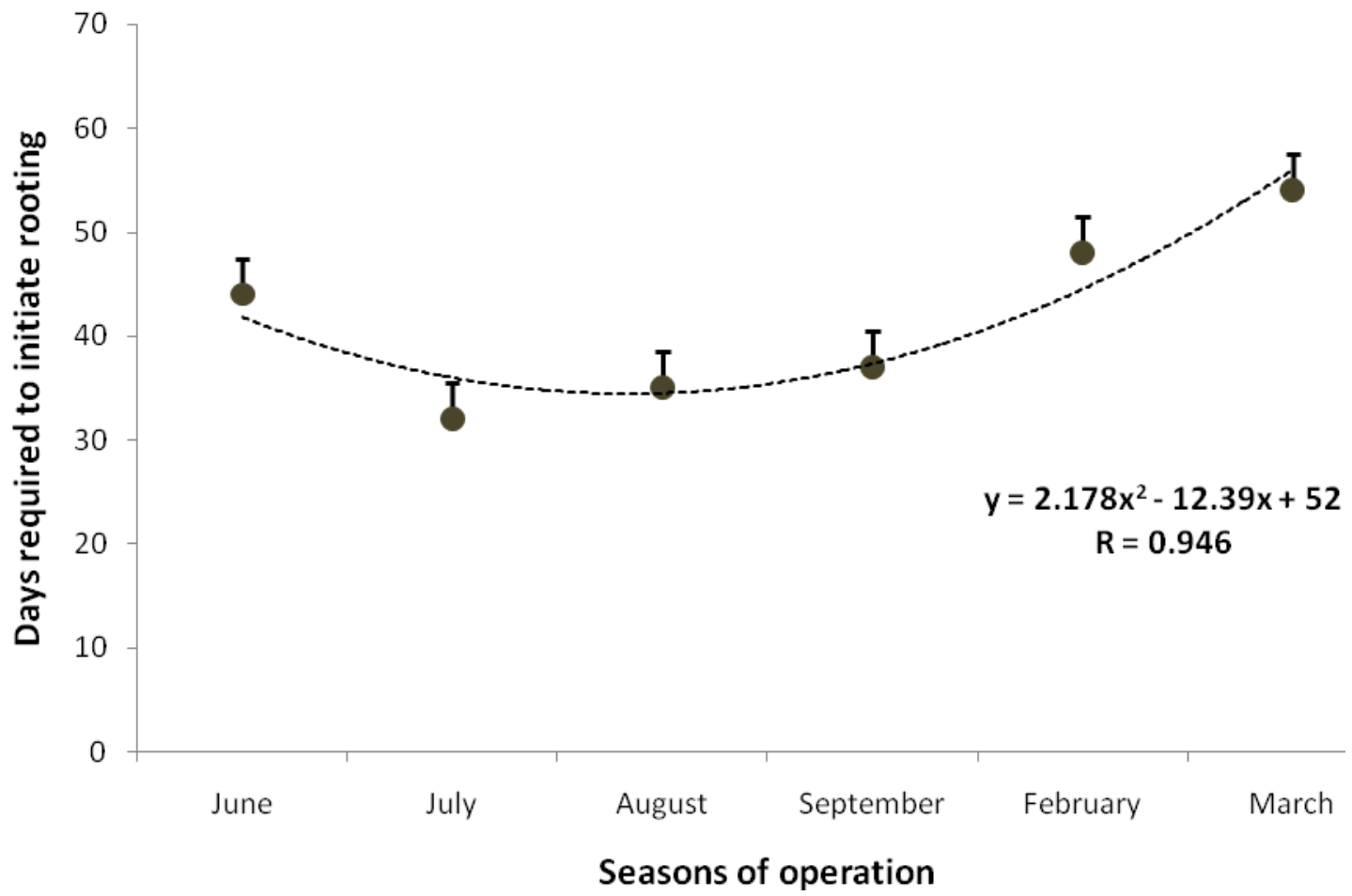


Fig.2 Effect of seasons of operation on success percentage of air layers. Vertical bars represent LSD at $5 \%$ probability level

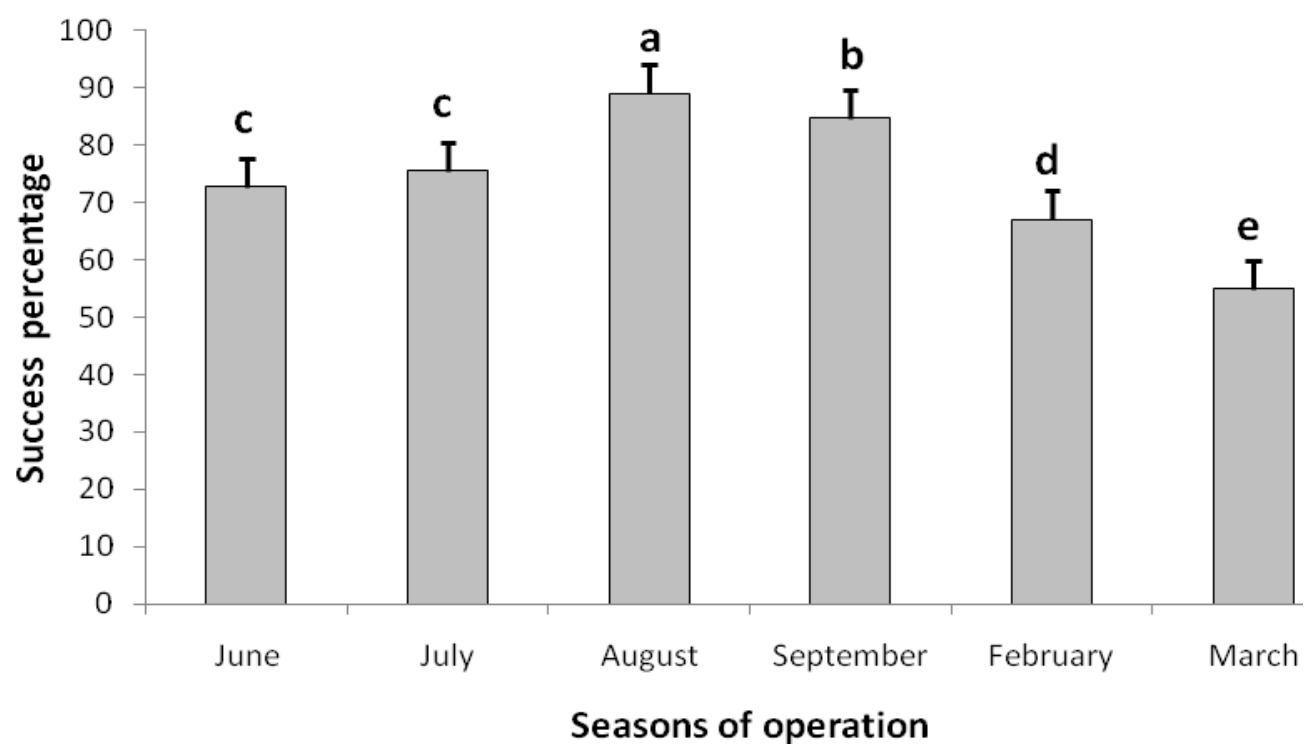

The trend of data on dry weight $(\mathrm{gm})$ revealed a corresponding lower values to that of fresh weight $(\mathrm{gm})($ Table 1$)$, where a significant (p $<0.05$ ) highest value was observed in the month of July (1.05 gm). The similar causes, as in the fresh weight may the probable reason for the results obtained in dry weight. These results corroborates the findings of Tomar (2011) in guava, but differed with the findings of Kumar et al., (2000) where they obtained higher values through application higher concentration of indole butyric acid ranging from 2000 to $12000 \mathrm{ppm}$.

In spite of the sincere effort, our study suffers from certain limitations like it pertains to only a particular agro ecological zone and a cultivar. Besides the use of hormones and other practices to enhance the success percent could not be exploited due to manpower and infrastructure constraints. Hence future studies can be focused in these areas to generate more information for better results.

In conclusion, it can be deduced from the present study that there is a possibility to extend the time of operation of air layering to other seasons, which allows generation of more number of planting materials. This is evident from the fact that performance of certain parameters (number of leaves, shoot length and root length) are either at par or better when conducted during spring and early summer. However, success percent and other growth parameters (days to initiation, number of primary and secondary root, fresh and dry weight) showed better results when performed during monsoon season, which suggest that there is a need for further research using combination of various factors to obtain better results in all the season.

\section{References}

Abbas, M.M., Roza, M.K., Ishfaq, M., Sharif, N. And Ahmad, S. (2016). Effect of Different Concentrations of NAA on Air Layering of Litchi (Litchi chinensis Sonn.). Proceedings of Pakistan Society for Horticultural Science, 2nd International Conference 
on Horticultural Sciences, February $18-20$.

Abutiate, W.S. and Nakasone, N. Y. (1972). Studies on vegetative propagation of lychee (Litchi chinensis Sonn.) with special reference to graftage. Ghana Journal of Agricultural Science, 5: 201-211.

Ali, M., Rab, A, Ahmad, H., Hayat, S., Wali, K. and Ali, J. (2016). The Influence of Different Media on Rooting of Litchi Plant through Air Layering. New Media and Mass Communication. 47. 12-15.

Almeida, E. J., Jesus, N., Ganga, R. M. D., Benassi, A. C., Scaloppi Júnior, E. J., Martins, A. B. G. (2004). Propagação de Dovyalis sp. pelo processo de mergulhia aérea. Revista Brasileirade Fruticultura Jaboticabal, v. 26, n. 3, p.511-514.

Amin, M.N., M.A. Razzaque, and M. Anisuzzaman. 1996. Regeneration of plants in vitro from seedling explants of lychee (Litchi chinensis Sonn.). In: Plant Tissue Culture. 21-25.

Bouma, T. J., Nielson, K. L., Koutsaal, B. (2000). Sample preparation and scanning protocol for computerized analysis of root length and diameter. Plant and Soil, Dordrecht, v. 218, n. 1/2, p. 185- 196.

Dhillon, B. S. and Mahajan, B. V. C. 2000. Effect of Different Dates on the Air Layering Performance of Litchi Cultivars in Sub-Mountainous Region of Punjab. Agricultural Science Digest. 20(3): 207-208.

Dhillon, B. S. and Mahajan, B. V. C. 2000. Effect of Different Dates on the Air Layering Performance of Litchi Cultivars in Sub-Mountainous Region of Punjab. Agricultural Science Digest. 20(3): 207-208.

Hartmann, H. T., Kester, D. E., Davies júnior, F. T., Geneve, R. L. 2011. In: Plant propagation: principles and practices. 8th ed. New Jersey: Prentice Hall, p. 915.

Hartmann, H.T., D. Kester, F.T. Davies, Jr., and R.L. Geneve. 2002. In: Plant propagation: Principles and practices. Pearson Education Inc., N.J.

Kadambi K and Dabral SN (1954) Air layering in Forestry practice. Indian Forester 81: 721-724.

Kumar, R. (2012), Off season air layering in litchi : A prudent and efficient approach. Technical Bulletin-6, NRC for Litchi Mushahari, Muzaffarpur, Bihar, pp.13.

Kumar, R. 2000. Role of season in multiplication of litchi (Litchi chinensis Sonn) in sub-humid conditions. Haryana J. horticultural Science. 29(1\&2): 55.

Kumar, R. 2000. Role of season in multiplication of litchi (Litchi chinensis Sonn) in sub-humid conditions. Haryana J. horticultural Science. 29(1\&2): 55.

L.C.R. de Lins, L.C.C. Salomao, P.R. Cecon and D.L. Siquera (2015). The lychee tree propagation by layering. Revista Brasileirade Fruticultura Jaboticabal (31): 480-487.

Lavania, M. L., Jain, S. K. and Lavania, S. K. 1995. Effect of Indole Butyric Acid on Air Layering in Jack Fruit (Artocarpus Heterophyllus Lam.). Ann. Agric. Res. 16(3): 387-388.

Lima, D. M., Biasi, L. A., Zanette, F., Zuffellato-Ribas, K. C., Bona, C., Mayer,J. L. S. 2011. Capacidade de enraizamento de estacas de Maytenus muelleri Schwacke com a aplicação de ácido indolbutírico relacionada aos aspectosanatômicos. Revista Brasileira de Plantas Medicinais, Botucatu, v.13, n. 4, p.422-438.

Lima. J.F., Silva. M.P.L., Teles. S., Silva. F., Martins. G.N. 2010. Avaliação de diferentes substratos na qualidade 
fisiológica de sementes de melão de caroá (Sicana odorifera (Vell.) Naudim). Revista Brasileira de Plantas Medicinais 12: 163-167.

Mergen, F. 1954. Anatomical studies of slash pine graft union. Q. Fla. Acad. Sci. 17: 238-245.

Nautiyal D.P. 2002. Vegetative Propogation in three important fodder tree species of family Moraceae from Garhwal Himalaya, Ph.D. Thesis submitted to H.N.B. Garhwal University, Srinagar, Uttarakhand, India.

Patel, B. B., Tank, R. V. and Bhandari, A. J. 2012. Response of the rootstocks and varieties on the growth and survival percentage in epicotyls grafting of mango (Mangifera indica L.). The Bioscan. 11(1): 479-483.

Patil, A. B., Jones, N. P and Patil, B. R. 2004. Studies on promotion of rooting in air layering of pomegranate as influenced by microbial inoculants. Karnataka $J$. Agricultural Sciences. 17(4): 861-863.

Rahman, M.A., Amin, M.N., Islam, M.S., Begum, M.M. and Uddin, M.A. (2002). Rooting and survival of air layers in litchi as influenced by layering time and plant growth regulator. Pakistan Journal of Biological Science. 5 (11): 1259-1260.

Rajendra P. Maurya1, Dion M. Lewis, and Jeff St. A. Chandler. Studies on the Propagation of Jamaican Ackee (Blighia sapida L.) by Air-layering.
Hortscience 48(10): 1298-1300. 2013.

Rios, E. S., Pereira, M. C., Santos, L. S., Souza, T. C., Ribeiro, V. G. 2012. Concentrações de ácido indolbutírico, comprimento e época de coleta de estacas, na propagação de umbuzeiro. Revista Caatinga, Mossoró, 25(1): 5257.

Ruiz-Sánchez, M. C., Plana, V., Ortuño, M. F., Tapia, L. M., Abrisqueta, J. M. 2005. Spatial root distribution of apricot trees in different soil till age practices. Plant and Soil, Dordrecht, 272(1/2): 211-221.

Singh, M. 2002. Response of plant growth regulators and wrappers on airlayering of guava (Psidium guajava L.). Advances in Plant Science. 15(I): 153-157.

Souza, J.M.A., Leonel, S., Reis, L.L.D., Ferraz, R.A. and Goncalves, B.H.L. (2016) Biostimulant and substrates on litchi tree propagation by air layering. Comunicata Scientiae 7(1): 122-128.

Sud, G. S. 2005. Effect of spacing of rooted layers on the success and growth of plants in litchi nursery. The Horticultural Journal Vol. 18(1): 6970.

Wahab, F., G. Nabi, N. Ali and M. Shah. 2001. Rooting response of semi hardwood cuttings of guava (Psidium guajava $L$.) to various concentrations of different Auxins. J. Biol. Sci. 1(4):184-187.

\section{How to cite this article:}

Ezekiel Reang, Julius Uchoi and Hidangmayum Lembisana Devi. 2018. Performance of Litchi (Litchi Chinensis Sonn.) Air Layers during Different Season: A Need for Optimization of Layering Period. Int.J.Curr.Microbiol.App.Sci. 7(08): 2607-2614.

doi: https://doi.org/10.20546/ijcmas.2018.708.268 